\title{
Numerical Simulation for Hot Dry Rock Geothermal Well Temperature Field
}

\author{
Hao Yang1, Yuan Shao² \\ ${ }^{1}$ China University of Geosciences, Beijing, China \\ ${ }^{2}$ Oil \& Gas Technology Research Institute, Petrochina Changqing Oilfield Company, Xi'an, China \\ Email: yanghao@cugb.edu.cn
}

How to cite this paper: Yang, $H$. and Shao, Y. (2017) Numerical Simulation for Hot Dry Rock Geothermal Well Temperature Field. Advances in Chemical Engineering and Science, 7, 34-44. http://dx.doi.org/10.4236/aces.2017.71004

Received: August 19, 2016

Accepted: December 18, 2016

Published: December 21, 2016

Copyright $\odot 2017$ by authors and Scientific Research Publishing Inc. This work is licensed under the Creative Commons Attribution International License (CC BY 4.0).

http://creativecommons.org/licenses/by/4.0/

Open Access

\begin{abstract}
Study on temperature distribution simulation during cementing of hot dry rock (HDR) geothermal well is rare. It has important guiding significance to simulate the construction process of temperature distribution of hot dry rock on site construction. Based on numerical simulation of HDR considering heat-fluid-solid coupling, the influence of temperature distribution on well cementing is analyzed when the drilling fluid cycles and reaches stable state, respectively, and when the cement slurry is injected during the cementing process. It is found that the seepage at the well bottom accelerates the flow velocity of wellbore; the stable temperature change is less than the cyclic temperature change; and the upper and lower temperature variation of the stratum is greater when the cement slurry is injected. Therefore, as to cement retarder involved, the influence of temperature variation on concretion should be considered during cementing of the hot dry rock geothermal well.
\end{abstract}

\section{Keywords}

Hot Dry Rock, Geothermal Well, Temperature Field, Numerical Simulation

\section{Horizontal Temperature Field Simulation}

Currently, articles on the simulation of downhole temperature field during well cementing are in a limited number, and especially those on simulating the temperature field of hot dry rock (HDR) well cementing are comparatively rare. By simulating the horizontal and vertical distribution of the HDR downhole temperature field, we investigated the distributing characteristics and influential factors of HDR downhole temperature field, aiming at guiding operation of HDR well cementing.

\subsection{Geometric Model Building}

When the depth of hot dry rock (HDR) well is reaching $1000 \mathrm{~m}$, heat-fluid-solid coupling should be considered for HDR numerical simulation, where both stratum 
thickness and radius are $1 \mathrm{~m}$; the borehole diameter and length are $0.25 \mathrm{~m}$ and $1 \mathrm{~m}$, respectively; the relevant wall thickness and length of drill pipe are $0.015 \mathrm{~m}$ and $0.9 \mathrm{~m}$, respectively; and the length of drill bit is $0.05 \mathrm{~m}$, as shown in Figure 1 .

\subsection{Governing Equation}

1) Flow equation

Flow in free and porous media is applied, which should satisfy the continuity equation:

$$
\rho \frac{\partial u}{\partial t}+\rho(u \cdot \nabla) u=\nabla \cdot\left[-p 1+\mu\left(\nabla u+(\nabla u)^{T}\right)\right]+F
$$

where $\rho$ is fluid density, $\mathrm{kg} / \mathrm{m}^{3}$; $t$ is time, $\mathrm{s} ; \mu$ is fluid viscosity, $\mathrm{Pa} \cdot \mathrm{s}$; $T$ is temperature, $\mathrm{K} ; F$ is volume force, $\mathrm{Pa}$; Total differential Displacement is $u=u(t, x, y)$.

2) Temperature distribution

In the present model, heat transfer within HDR stratum, fluid, drill stem and drill bit in the borehole is considered. Assume that no heat was generated from drill bit, and then the continuity equation of the relevant heat circulation is as follows:

$$
\left(\rho c_{p}\right)_{e q} \frac{\partial T}{\partial t}+\rho c_{p} u \cdot \nabla T=\nabla \cdot\left(k_{e q} \nabla T\right)+Q
$$

where, $\rho$ is fluid density, $\mathrm{kg} / \mathrm{m}^{3} ; t$ is time, $\mathrm{s} ; \quad T$ is temperature, $\mathrm{K} ; K_{e q}$ is thermal conductivity coefficient, $\mathrm{W} /(\mathrm{m} \cdot \mathrm{K}) ; c_{p}$ is specific heat capacity, $\mathrm{J} /(\mathrm{kg} \cdot \mathrm{K}) ; Q$ is Heat source, $\mathrm{W} / \mathrm{m}^{3}$.

3) Convection heat transfer

The governing equation of convection heat transfer between drilling fluid and well wall is given below,

$$
-n(-k \nabla T)=h\left(T_{e s t}-T\right)
$$

where $k$ is thermal conductivity coefficient, $[\mathrm{W} / \mathrm{m} \cdot \mathrm{K}] ; T$ is temperature, $\mathrm{K} ; n$ is

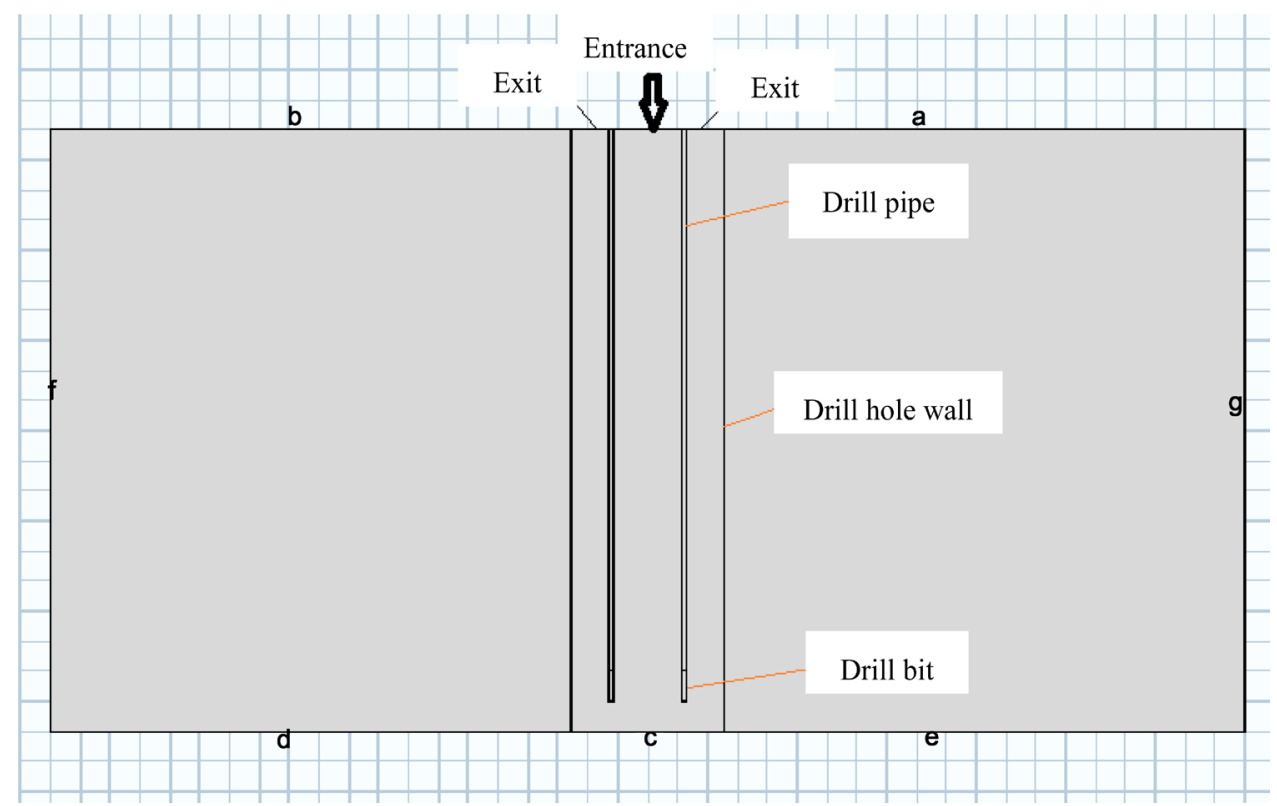

Figure 1. Diagram of the geometric model. 
normal vector of solid surface; $h$ is convective heat transfer coefficient, $\left[\mathrm{W} / \mathrm{m}^{2} \cdot \mathrm{k}\right]$; $T_{e s t}$ is fluid near-surface temperature.

\subsection{Boundary and Initial Value}

The drilling fluid flows in from the entrance and flows out from the exit as for seepage field. Boundaries $a, b, d, e, f$ and $g$ are set as six seepage boundaries, and $c$ is set as the seepage wall with a seepage velocity of $8-10 \mathrm{~m} / \mathrm{s}$. The surfaces of drill pipe and drill bit are set as non-slip wall. The entrance boundary is set as the velocity boundary with a value of $3 \mathrm{~m} / \mathrm{s}$, and the velocity of exit boundary is set as zero, with no viscous stress.

As for temperature field, considering heat transfer in the porous media, the values for boundaries $a, b$, exit and entrance boundaries are all $293.15 \mathrm{~K}$, while those of the borehole wall and boundaries $f$ and $g$ are $3^{\circ} \mathrm{C} / 100 \mathrm{~m}$, calculated according to geothermal gradient; considering heat transfer in the fluid, the exit and entrance temperatures are also set as $293.15 \mathrm{~K}$; the external temperature concerning convection heat transfer is set the same as borehole wall temperature. The detailed boundary information is shown in Figure 1. The figure was established according to the general structure of hot dry rock drilling.

\subsection{Parameter Selection}

HDR stratum parameters [1]-[10] are used here regarding stratum to be investigated, and polymer drilling fluid is utilized. The materials [11] [12] [13] [14] of drill pipe and drill bit are alloy and diamond, respectively. Detailed information of the above mentioned parameters is shown in Table 1.

\subsection{Mesh Division}

Mesh division of the geometric model is shown in Figure 2, through using grid refinement method near the wellbore appropriately, and considering the calculation workload.

Table 1. Model parameters.

\begin{tabular}{cccc}
\hline Well depth & $1000 \mathrm{~m}$ & Pore water heat conductivity coefficient & $0.5 \mathrm{~W} /(\mathrm{m} \cdot \mathrm{K})$ \\
Geothermal gradient & $3^{\circ} \mathrm{C} / 100 \mathrm{~m}$ & Slurry density & $1300 \mathrm{~kg} / \mathrm{m}^{3}$ \\
Rock density & $2700 \mathrm{~kg} / \mathrm{m}^{3}$ & Specific heat capacity of slurry & $2800 \mathrm{~J} /(\mathrm{kg} \cdot \mathrm{K})$ \\
Specific heat capacity of rock & $1400 \mathrm{~J} /(\mathrm{kg} \cdot \mathrm{K})$ & Surface heat transfer coefficient & $200 \mathrm{~W} /\left(\mathrm{m}^{3} \cdot \mathrm{K}\right)$ \\
Rock heat conductivity coefficient & $10 \mathrm{~W} /(\mathrm{m} \cdot \mathrm{K})$ & Slurry heat conductivity coefficient & $1 \mathrm{~W} /(\mathrm{m} \cdot \mathrm{K})$ \\
Porosity & 0.1 & Drill pipe heat conductivity coefficient & $17 \mathrm{~W} /(\mathrm{m} \cdot \mathrm{K})$ \\
Permeability & $1 \mathrm{e}-14(\mathrm{D})$ & Drill pipe density & $7800 \mathrm{~kg} / \mathrm{m}^{3}$ \\
Internal friction angle & $30^{\circ}$ & Drill pipe atmospheric heat capacity & $460 \mathrm{~J} /(\mathrm{kg} \cdot \mathrm{K})$ \\
Poisson's ratio & 0.3 & Drill bit density & $3200 \mathrm{~kg} / \mathrm{m}^{3}$ \\
Biot coefficient & 1 & Drill bit heat conductivity coefficient & $1500 \mathrm{~W} /(\mathrm{m} \cdot \mathrm{K})$ \\
Pore water density & $1000 \mathrm{~kg} / \mathrm{m}^{3}$ & Drill bit atmospheric heat capacity & $400 \mathrm{~J} /(\mathrm{kg} \cdot \mathrm{K})$ \\
Pore water specific heat capacity & $4200 \mathrm{~J} /(\mathrm{kg} \cdot \mathrm{K})$ & Heat transfer coefficient & $200 \mathrm{~W} /\left(\mathrm{m}^{2} \cdot \mathrm{K}\right)$ \\
\hline
\end{tabular}




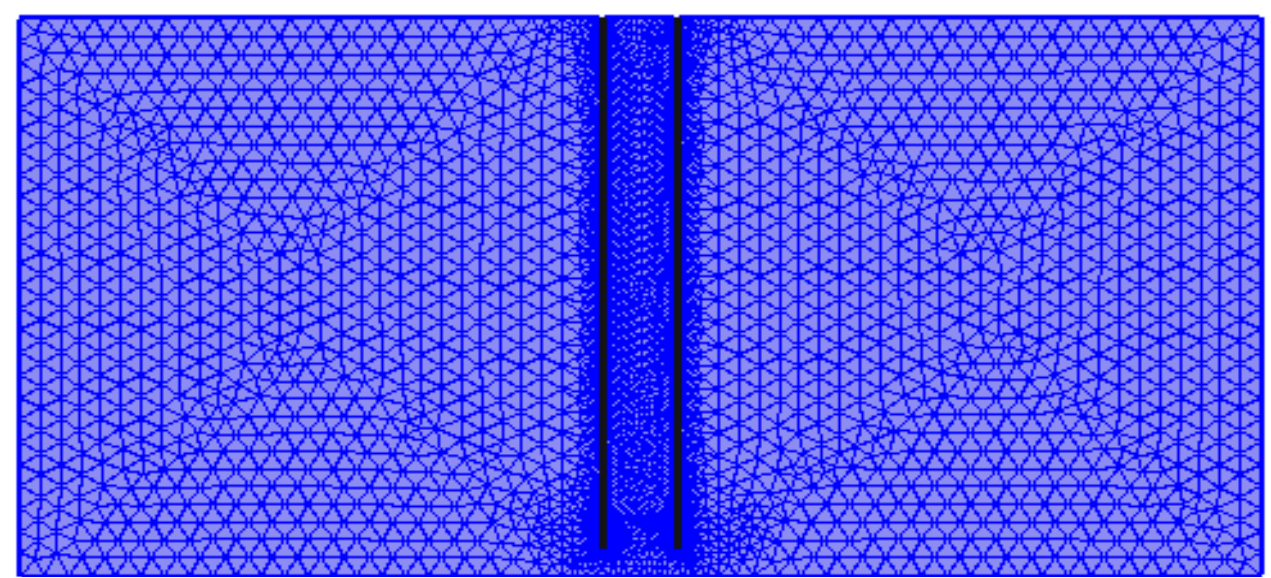

Figure 2. Mesh division of the geometric model.

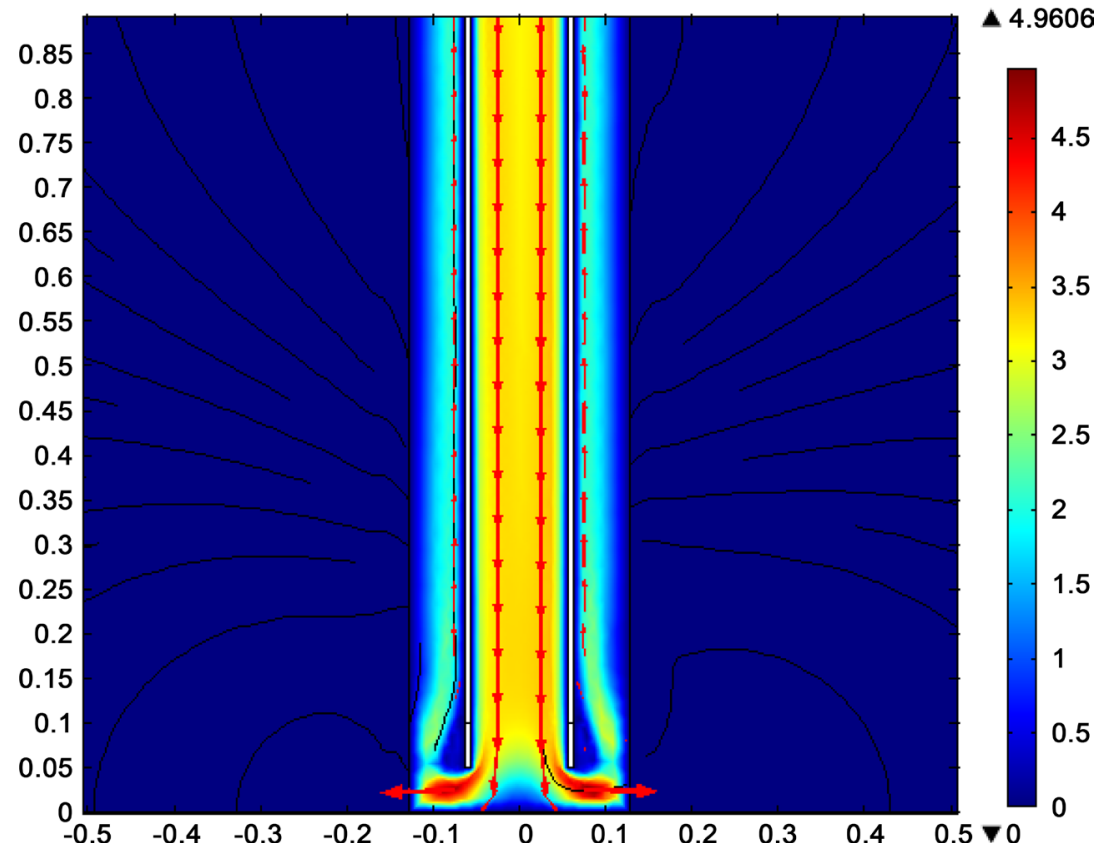

Figure 3. Velocity distribution after $1 \mathrm{~h}$ of circulation.

\subsection{Analysis of Result}

1) Flow field simulation of HDR stratum

Four individual seepage velocities under the well of $10^{-4} \mathrm{~m} / \mathrm{s}, 10^{-8} \mathrm{~m} / \mathrm{s}, 10^{-12} \mathrm{~m} / \mathrm{s}$ and $0 \mathrm{~m} / \mathrm{s}$ are used for simulation and calculation, among which the simulation result corresponding to $10^{-4} \mathrm{~m} / \mathrm{s}$ is shown in Figure 3. Velocities of the drilling fluid at the bottom of the well related to different seepage velocities are listed in Table 2.

Clearly, the permeability of the well bottom can affect the flow of drilling fluid. The flow velocity at the bottom of the well increases with better well bottom permeability. However, the influence is generally very small, and thus can be ignored.

In Figure 3, different colors refer to different velocity. The red arrow represents the flow line while the black line refers to the seepage of pore water. It can be observed that the drilling fluid velocity is decreasing in the field close to the drill pipe wall and well wall, and the velocity at the drill bit is the highest. Data is the actual discrete, the actual 
grid may not completely symmetrical.

2) HDR temperature field simulation

In Figure 4, the continuous and discontinuous color legend refers to the geothermal gradient and stratum isotherm, respectively. From analysis of Figure 4, it can be found that during the circulation of drilling fluid, when the temperature of returning drilling fluid under certain well depth is lower than the stratum temperature, the temperature of the upward moving fluid will be raised via continuously absorbing the heat from the well wall rock, thus resulting in temperature decrease of well wall rock due to heat loss. With the circulation of drilling fluid in the well arriving at a stable state, the heat exchange between drilling fluid in the well and well wall rock reaches a balance state gradually, thus the temperature difference between them also decreases gradually. When the time is long enough for drilling fluid keeping stable, the temperature of the drilling fluid in the well will gradually approaches the earth temperature. Therefore, as a function of time, the stratum temperature near the well wall, is a problem concerning transient heat transfer.

In Figure 4, the color legends refer to the geothermal gradient and stratum isotherm separately.

\section{Longitudinal Temperature Field Simulation}

\subsection{Longitudinal Simulation of Well Structure (Example)}

As for HDR geothermal well, the well surface and bottom temperatures are $20^{\circ} \mathrm{C}$ and

Table 2. Flow velocity corresponding to different seepage velocities at the bottom of the well.

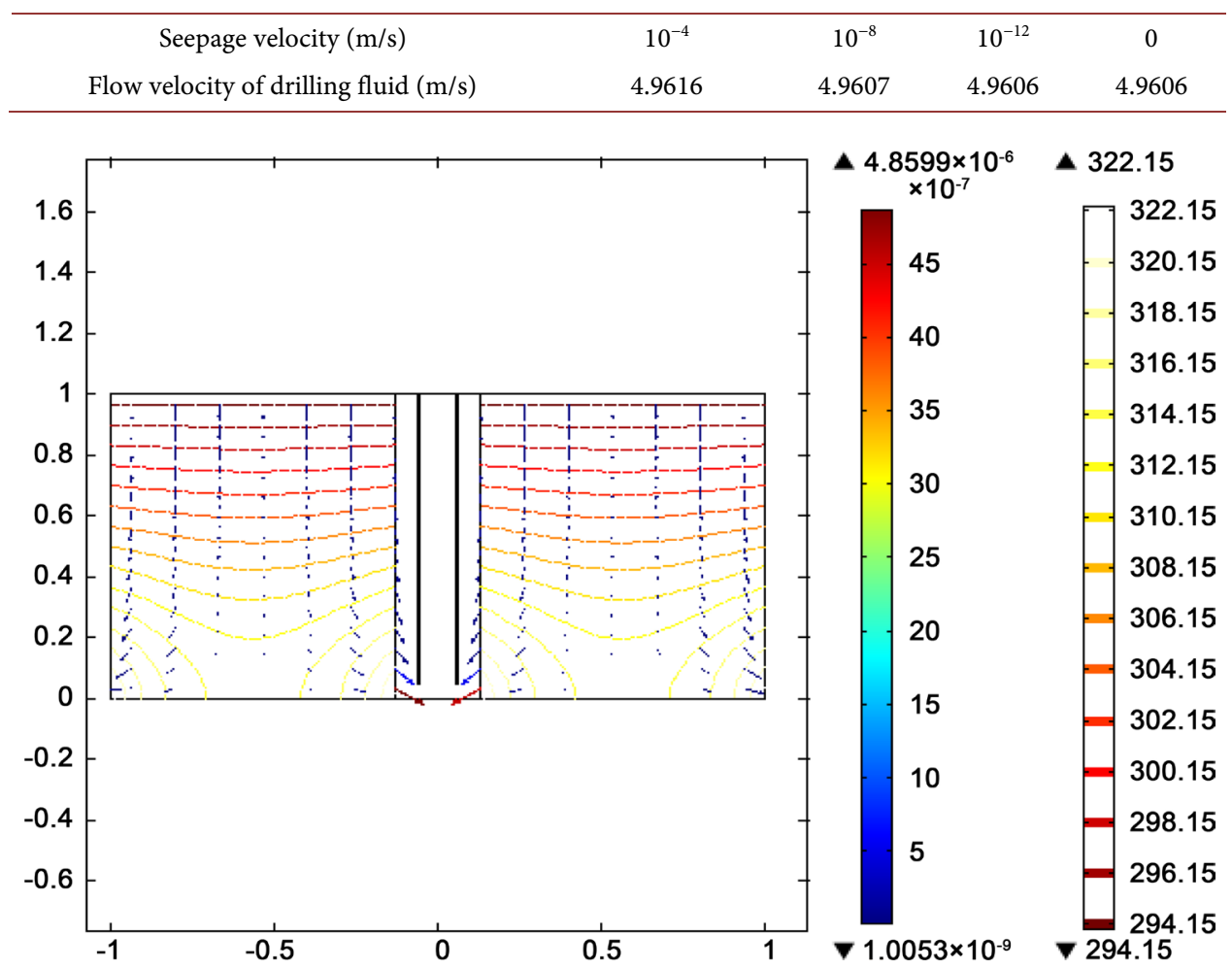

Figure 4. Stratum temperature distribution and geothermal gradient (Drilling fluid circulation after $60 \mathrm{~min})$. 
$220^{\circ} \mathrm{C}$ respectively, and the well depth is $2000 \mathrm{~m}$. Well structure is shown in Figure 5.

\subsection{Continuous Circulation Simulation of Temperature Distribution before Well Cementing}

Simulation results of temperature distribution of circulating drilling fluid at $0 \mathrm{~h}, 1 \mathrm{~h}, 5$ h, 10 h, 24 h, $48 \mathrm{~h}$ and $96 \mathrm{~h}$ are presented in Figure 6. It can be observed that the temperature of upper stratum increases with increasing circulation time, but that of lower stratum decreases. Seen from Figure 7, it can be found that the temperature variation of upper part is smaller than that of lower part. During 96 hours' circulation simulation, the temperature variation at selected time of upper stratum is within $10^{\circ} \mathrm{C}$, while that of lower stratum exceeds $20^{\circ} \mathrm{C}$.

\subsection{Discontinuous Circulation Simulation of Temperature Distribution before Well Cementing}

Figure 8 shows temperature variation at seven different times during 96 hours' circulation simulation, but the difference between that shown in Figure 7 is that individual temperature is obtained on condition that the circulation is stopped at certain selected

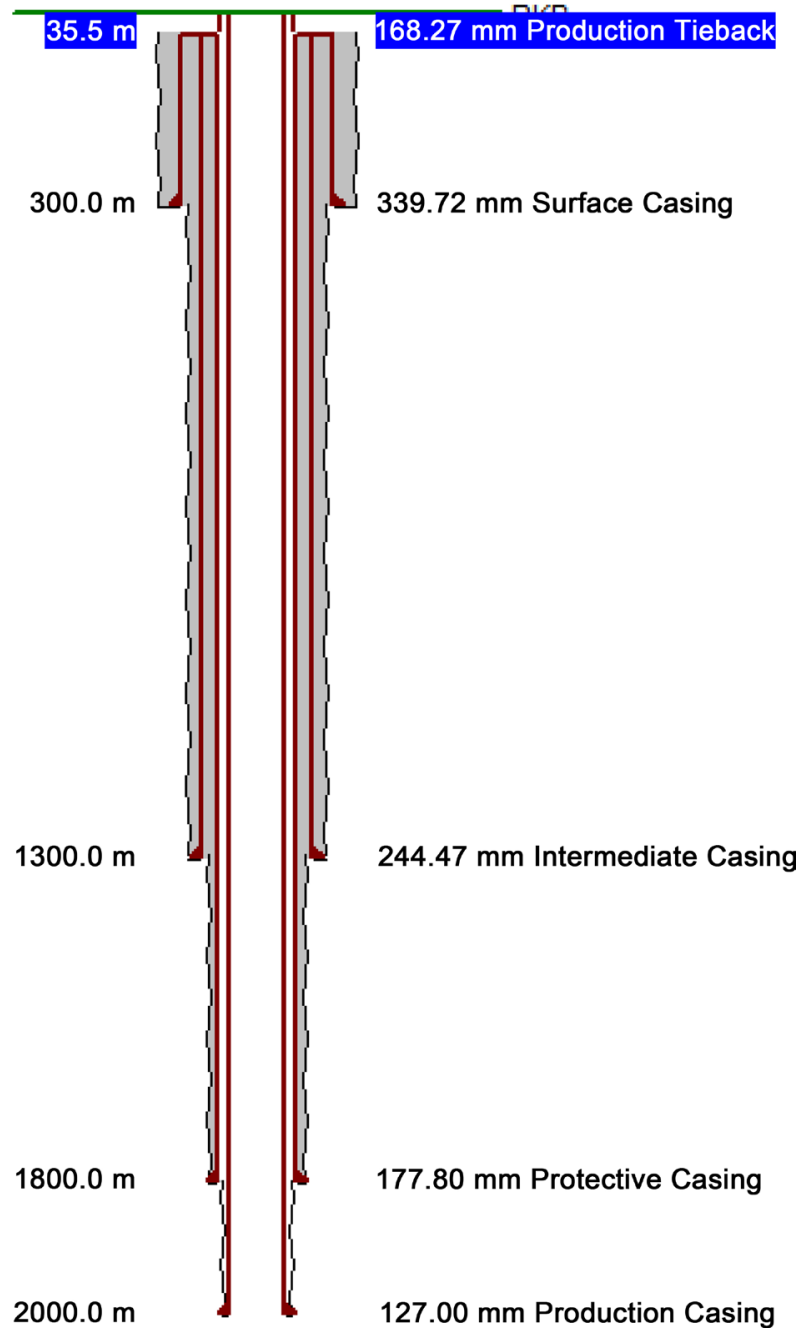

Figure 5. Configuration of well structure for longitudinal temperature simulation. 


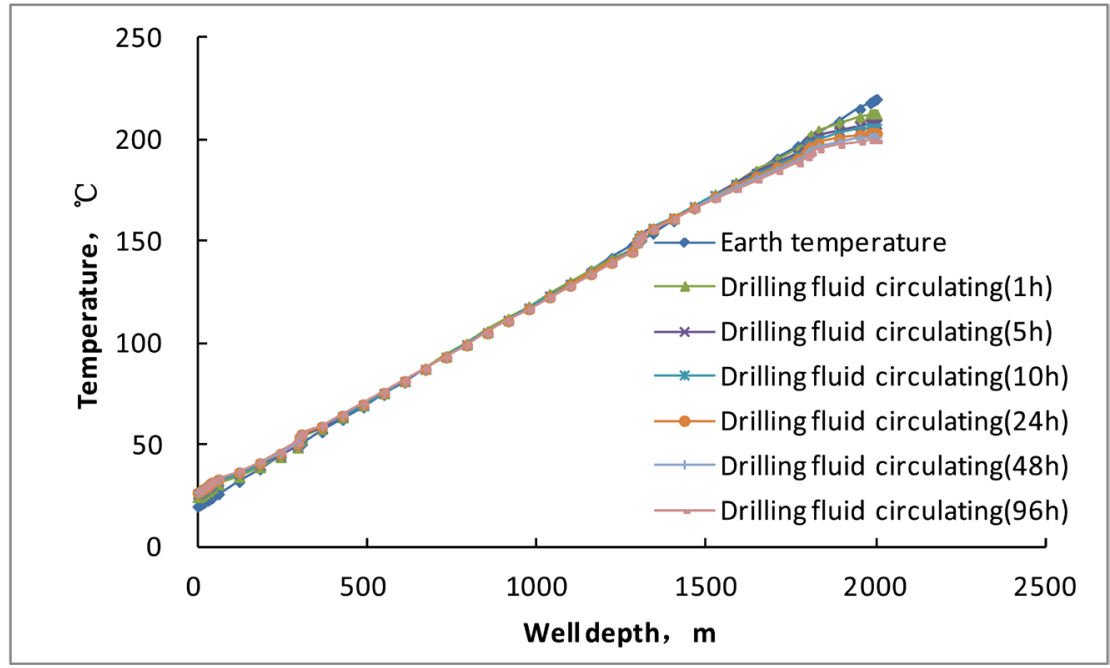

Figure 6. Comparison of annular space temperature of circulating drilling fluid at different time.

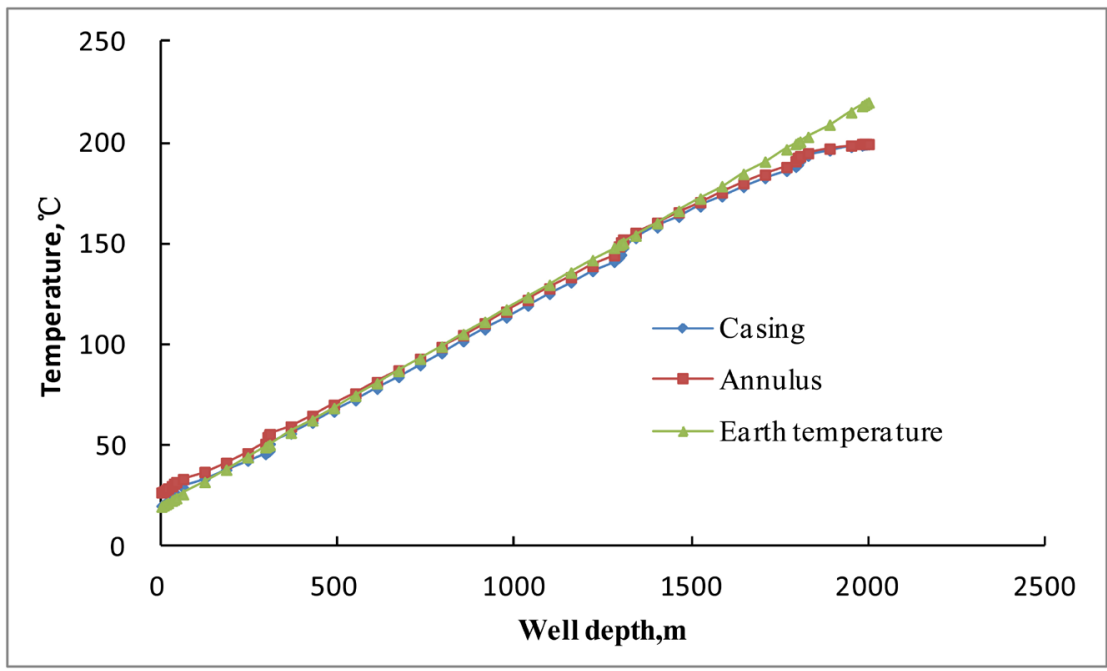

Figure 7. Comparison of annular space, sleeve and earth temperature after $96 \mathrm{~h}$ circulation of drilling fluid.

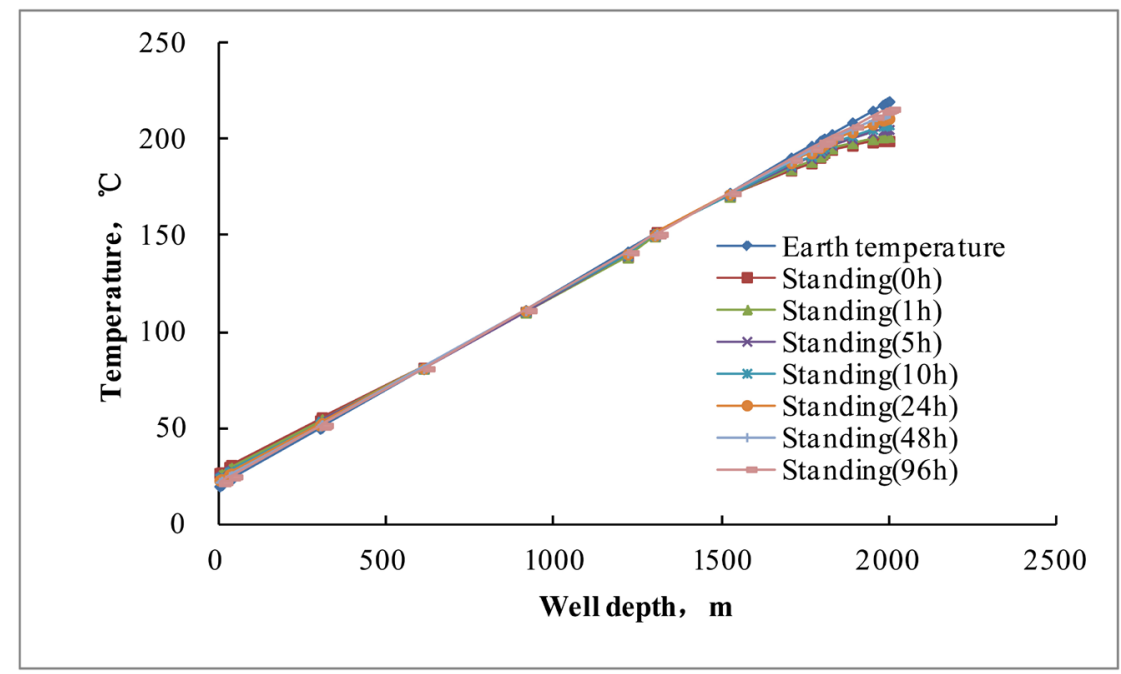

Figure 8. Recovery temperature at different time. 
time. The temperature at different stopping time of upper part decreases while that of lower part increases. Comparison of temperature distribution at different stopping time reveals that temperature variation of upper and lower parts are $5^{\circ} \mathrm{C}$ and $16^{\circ} \mathrm{C}$, respectively, and temperature difference of upper annular space is far smaller than that of lower part. Meanwhile, regarding comparison between Figure 6 and Figure 8, it can be found that temperature change of discontinuous case is less than that of continuous case.

\subsection{Temperature Variation during Injection of Cement Slurry}

After being stable for $96 \mathrm{~h}$, the ahead fluid and cement slurry will be injected successively, and then the relevant temperature variation of the annular space is shown in $\mathrm{Ta}$ ble 3.

Table 3. Annular space temperature variation during injection of cement slurry.

\begin{tabular}{|c|c|c|c|c|c|c|c|c|c|c|c|c|c|c|}
\hline $\begin{array}{l}\text { Well } \\
\text { depth }\end{array}$ & $\begin{array}{c}\text { Earth } \\
\text { temperature }\end{array}$ & $\begin{array}{c}\text { Standing } \\
96 \mathrm{~h}\end{array}$ & $\begin{array}{c}\text { Ahead } \\
\text { fluid } \\
\text { injection }\end{array}$ & $\begin{array}{c}\text { Cement } \\
\text { slurry } \\
\text { injection } \\
(1 \mathrm{~h})\end{array}$ & $\begin{array}{c}\text { Cement } \\
\text { slurry } \\
\text { injection } \\
(2 \mathrm{~h})\end{array}$ & $\begin{array}{c}\text { Cement } \\
\text { slurry } \\
\text { injection } \\
(3 \mathrm{~h})\end{array}$ & $\begin{array}{c}\text { Cement } \\
\text { slurry } \\
\text { injection } \\
(4 \mathrm{~h})\end{array}$ & $\begin{array}{c}\text { Cement } \\
\text { slurry } \\
\text { injection } \\
(5 \mathrm{~h})\end{array}$ & $\begin{array}{c}\text { Subsequent } \\
\text { liquid } \\
\text { injection }\end{array}$ & $\begin{array}{l}\text { Waiting } \\
\text { on } \\
\text { cement } \\
\text { setting } \\
(1 \mathrm{~h})\end{array}$ & $\begin{array}{l}\text { Waiting } \\
\text { on } \\
\text { cement } \\
\text { setting } \\
(10 \mathrm{~h})\end{array}$ & $\begin{array}{c}\text { Waiting } \\
\text { on } \\
\text { cement } \\
\text { setting } \\
(24 \mathrm{~h})\end{array}$ & $\begin{array}{c}\text { Waiting } \\
\text { on } \\
\text { cement } \\
\text { setting } \\
\text { (48 h) }\end{array}$ & $\begin{array}{l}\text { Waiting } \\
\text { on } \\
\text { cement } \\
\text { setting } \\
\text { (96h) }\end{array}$ \\
\hline 0.0 & 20.00 & 21.32 & 26.69 & 36.17 & 37.72 & 38.67 & 39.31 & 39.77 & 27.34 & 26.23 & 24.44 & 23.17 & 22.17 & 21.37 \\
\hline 6.1 & 20.61 & 22.00 & 27.09 & 36.48 & 38.01 & 38.95 & 39.59 & 40.04 & 27.80 & 26.75 & 25.06 & 23.84 & 22.87 & 22.09 \\
\hline 29.4 & 22.94 & 24.40 & 29.69 & 38.59 & 39.99 & 40.87 & 41.46 & 41.89 & 30.64 & 29.59 & 27.67 & 26.34 & 25.30 & 24.48 \\
\hline 35.5 & 23.55 & 24.89 & 30.77 & 39.46 & 40.81 & 41.65 & 42.23 & 42.65 & 31.81 & 30.30 & 27.95 & 26.59 & 25.62 & 24.90 \\
\hline 300.0 & 50.00 & 50.73 & 53.82 & 61.86 & 62.57 & 63.03 & 63.36 & 63.60 & 55.27 & 54.14 & 52.74 & 51.92 & 51.30 & 50.84 \\
\hline 304.8 & 50.48 & 51.38 & 54.80 & 62.41 & 63.10 & 63.55 & 63.87 & 64.10 & 56.21 & 54.95 & 53.45 & 52.62 & 51.98 & 51.47 \\
\hline 306.1 & 50.61 & 51.61 & 55.37 & 62.72 & 63.40 & 63.84 & 64.16 & 64.39 & 56.91 & 55.84 & 53.98 & 52.96 & 52.24 & 51.67 \\
\hline 609.6 & 80.96 & 81.06 & 81.58 & 87.73 & 87.66 & 87.65 & 87.65 & 87.64 & 81.92 & 81.57 & 81.55 & 81.44 & 81.29 & 81.17 \\
\hline 914.4 & 111.44 & 111.29 & 111.10 & 115.95 & 114.94 & 114.31 & 113.86 & 113.53 & 109.37 & 109.39 & 110.52 & 110.97 & 111.17 & 111.29 \\
\hline 1219.2 & 141.92 & 141.37 & 139.64 & 141.91 & 140.02 & 138.70 & 137.88 & 137.30 & 135.63 & 136.11 & 138.80 & 140.03 & 140.73 & 141.19 \\
\hline 1300.0 & 150.00 & 150.17 & 151.25 & 149.76 & 147.53 & 146.14 & 145.29 & 144.66 & 146.11 & 145.95 & 147.90 & 148.89 & 149.43 & 149.74 \\
\hline 1306.1 & 150.61 & 150.97 & 152.67 & 150.24 & 147.98 & 146.59 & 145.75 & 145.11 & 147.50 & 147.36 & 148.95 & 149.74 & 150.17 & 150.43 \\
\hline 1524.0 & 172.40 & 172.12 & 171.58 & 169.39 & 165.37 & 162.51 & 160.39 & 158.68 & 165.24 & 165.77 & 168.76 & 170.20 & 171.05 & 171.62 \\
\hline 1706.9 & 190.69 & 189.51 & 185.87 & 186.09 & 182.53 & 179.61 & 177.27 & 175.33 & 178.67 & 180.02 & 184.92 & 187.05 & 188.32 & 189.21 \\
\hline 1767.8 & 196.78 & 195.15 & 189.75 & 190.21 & 186.68 & 183.72 & 181.31 & 179.30 & 182.22 & 183.90 & 189.78 & 192.31 & 193.81 & 194.87 \\
\hline 1793.9 & 199.39 & 197.84 & 192.75 & 192.86 & 189.31 & 186.31 & 183.84 & 181.78 & 184.88 & 186.48 & 192.41 & 194.98 & 196.49 & 197.56 \\
\hline 1800.0 & 200.00 & 198.69 & 194.53 & 193.96 & 190.40 & 187.38 & 184.88 & 182.78 & 186.42 & 187.84 & 193.49 & 195.94 & 197.37 & 198.37 \\
\hline 1806.1 & 200.61 & 199.30 & 195.43 & 194.40 & 190.84 & 187.81 & 185.29 & 183.18 & 187.35 & 188.91 & 194.25 & 196.53 & 197.90 & 198.91 \\
\hline 1828.8 & 202.88 & 201.44 & 197.17 & 195.37 & 191.79 & 188.73 & 186.18 & 184.05 & 188.92 & 190.70 & 196.18 & 198.53 & 199.96 & 201.02 \\
\hline 1889.8 & 208.98 & 206.72 & 199.58 & 197.08 & 193.41 & 190.26 & 187.64 & 185.44 & 191.05 & 193.41 & 200.24 & 203.20 & 205.04 & 206.44 \\
\hline 1950.7 & 215.07 & 211.88 & 201.22 & 197.67 & 193.85 & 190.58 & 187.87 & 185.60 & 192.45 & 195.43 & 203.85 & 207.54 & 209.85 & 211.63 \\
\hline 1981.7 & 218.17 & 214.47 & 201.73 & 196.76 & 192.82 & 189.47 & 186.70 & 184.39 & 192.85 & 196.16 & 205.50 & 209.63 & 212.26 & 214.29 \\
\hline 1987.8 & 218.78 & 214.99 & 201.75 & 195.91 & 191.93 & 188.55 & 185.76 & 183.45 & 192.84 & 196.22 & 205.75 & 209.98 & 212.67 & 214.76 \\
\hline 1993.9 & 219.39 & 215.46 & 201.71 & 195.56 & 191.57 & 188.17 & 185.38 & 183.07 & 192.79 & 196.26 & 206.00 & 210.34 & 213.10 & 215.24 \\
\hline 2000.0 & 220.00 & 215.95 & 201.61 & 195.17 & 191.16 & 187.75 & 184.96 & 182.65 & 192.71 & 196.29 & 206.27 & 210.73 & 213.56 & 215.76 \\
\hline
\end{tabular}


It can be observed from Table 3 and Figure 9, the temperature of the lower stratum is high but that of the upper stratum is low, and the temperature variation of the upper and lower stratum is larger, with a value about $40^{\circ} \mathrm{C}$. The cement slurry in lower position will solidify at first to avoid the bridge plug, because in general, the higher the temperature, the faster the cement solidification. Consequently, this whole process can help improve cementing quality. The temperature of subsequent cement slurry will be increased due to convective heat transfer from solidified cement in the lower position, thus its solidification can be quickened, without changing the condition that the cement temperature of lower layer is higher than that of the upper. During waiting on the cement setting stage, the subsequent annular space temperature will return to the stratum temperature gradually.

When conditions are ripe, we can test how the simulations correspond to the real experimental data.

\section{Conclusions}

1) The seepage at the bottom of the well can accelerate the velocity of flow in the wellbore, but the impact is negligible.

2) The temperature of upper stratum increases with the increase of circulation time, but the temperature variation of lower stratum has an opposite trend.

3) At stable circulation state, the temperature of upper part decreases, while that of lower part increases. The temperature variation of upper annular space is far lower than that of lower part in stable state. The temperature variation in stable state is less than

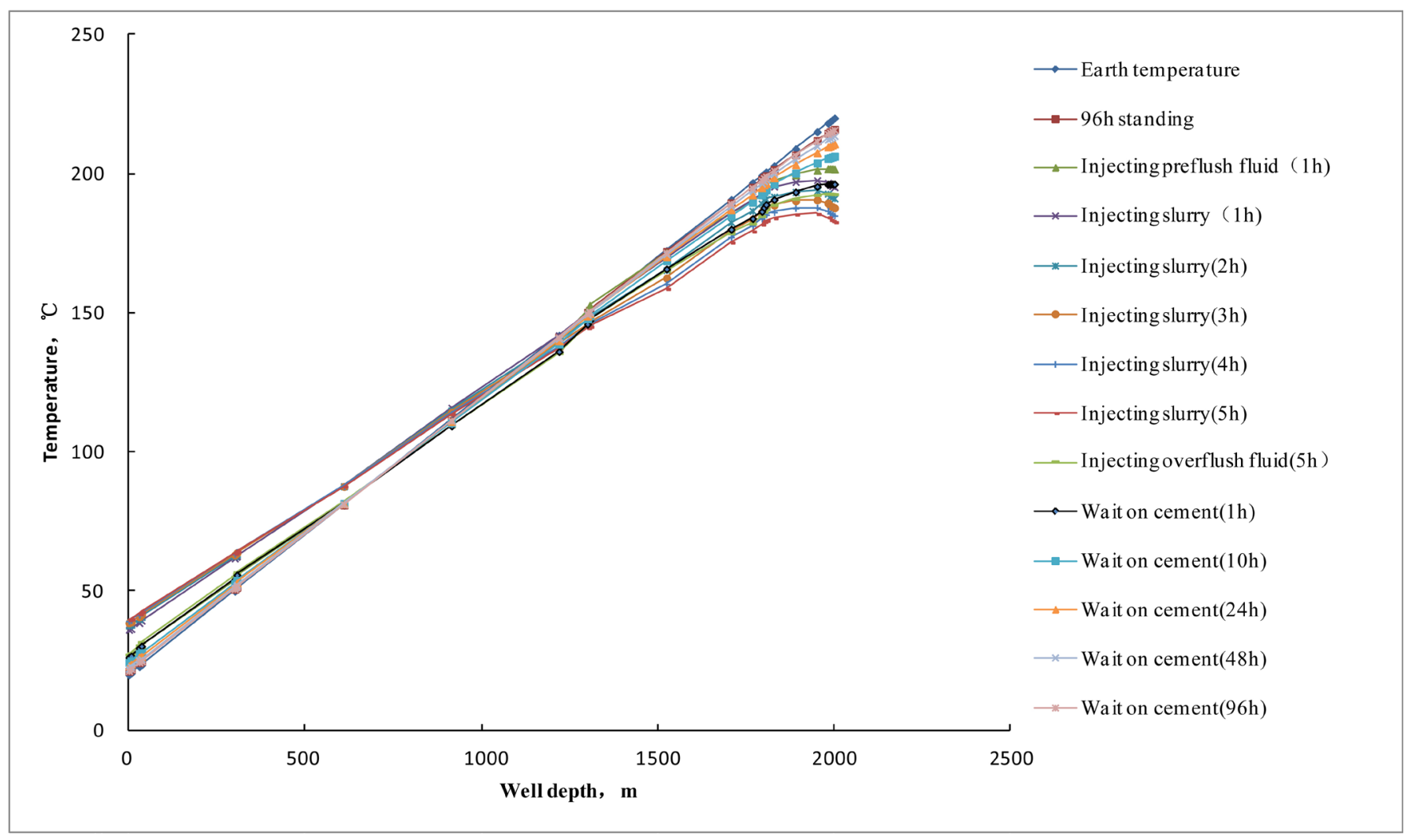

Figure 9. Temperature distribution during injection of cement slurry. 
that in cyclic state.

4) During injection of cement slurry, the temperature variation of upper and lower stratum is greater. During waiting on the cement setting period, the subsequent annular space temperature will return to stratum temperature gradually. Generally, the control agent of cement slurry solidification is very sensitive to temperature, so the influence of stratum temperature variation on cement slurry solidification should be considered during circulation of drilling fluid and injection of cement slurry, aiming at ensuring construction safety and increasing well cementing quality.

\section{Acknowledgements}

This research was supported by NSFC project "Study on the evolution mechanism of composite materials with high temperature resistance, high pressure resistance, and low elastic modulus", No. 51474192; and "Basic research funding of central universities", No. 2652015067.

\section{References}

[1] Shan, J.L. (2009) Study on Underground Heat Exchanger Performance Test and Model Design of Ground Source Heat Pump System. Chongqing University, Chongqing.

[2] Wang, M.G. (2007) Ground Source Heat Pump System Engineering Case Analysis. Chongqing University, Chongqing.

[3] Li, M. (2010) Buried Pipe Ground Source Heat Pump System Regional Adaptability Study [D]. NUST, Nanjing.

[4] Zhu, Q.Y., Xu, W. and Shen, L. (2010) Technical Code for Ground Source Heat Pump System Revised. Construction Technology, 18, 19-21.

[5] Xu, W., Zou, Y. and Feng, X.M. (2010) Advancement • Safety • Operability-National Standard Engineering Technical Code for Ground Source Heat Pump System Compilation Points. Construction Technology, 18, 10-12.

[6] Peng, L. (2008) Ground Source Heat Pump System Characteristics Research and Simulation Program Development. Chongqing University, Chongqing.

[7] Yang, F., Li, J. and Ren, X.J. (2012) China Hot Dry Rock Exploration and Exploitation Status. Resources Environment \& Engineering, 26, 339-341.

[8] Lin, W.J., Liu, Z.M., Ma, F., Liu, C.L. and Wang, G.L. (2012) China Land Zone Hot Dry Rock Resource Potential Estimation. Acta Geoscientica Sinica, 33, 807-811.

[9] Xu, T.F., Zhang, Y.J., Zeng, Z.F. and Bao, X.H. (2012) Enhanced Geothermal System (Hot Dry Rock) Development Technology Progress. Science \& Technology Review, 32, 42-45.

[10] Wang, J.Y., Hu, S.B., Pang, Z.H., et al. (2012) China Land Zone Hot Dry Rock Geothermal Resource Potential Assessment. Science \& Technology Review, 32, 25-31.

[11] Ran, H.Q. and Feng, Q.Z. (2010) Technology Problems Related to China Hot Dry Rock Exploration. Exploration Engineering (Drilling \& Tunneling Engineering of Rock and Soil), 37, 17-21.

[12] Yang, J.L. and Hu, K. (2001) Hot Dry Rock (HDR) Resource Study and Development Technology Overview. Global Geology, 20, 43-51.

[13] Feng, X.Y. (2012) Study on Utilization of Hot Dry Rock Resource for Heating Technology in Shenyang District. Shenyang Architecture University, Shenyang.

[14] Gamier, A., Saint-Marc, J., Kermanac, H.Y. and Bois, A. (2008) Singular Methodology to Design Cement Sheath Integrity Exposed to Steam Stimulation. Society of Petroleum Engi- 
neers, International Thermal Operations and Heavy Oil Symposium, ITOHOS 2008, Calgary, 20-23 October 2008, 1-15.

Submit or recommend next manuscript to SCIRP and we will provide best service for you:

Accepting pre-submission inquiries through Email, Facebook, LinkedIn, Twitter, etc. A wide selection of journals (inclusive of 9 subjects, more than 200 journals) Providing 24-hour high-quality service User-friendly online submission system Fair and swift peer-review system Efficient typesetting and proofreading procedure Display of the result of downloads and visits, as well as the number of cited articles Maximum dissemination of your research work

Submit your manuscript at: http://papersubmission.scirp.org/

Or contact aces@scirp.org 